\title{
Cavalier King Charles Spaniel
}

National Cancer Institute

\section{Source}

National Cancer Institute. Cavalier King Charles Spaniel. NCI Thesaurus. Code C53928.

The Cavalier King Charles Spaniel is a small spaniel with dark, round eyes that are large but not prominent. The ears are long with abundant feathering, and it has a silky coat, sometimes with a slight waviness that comes in ruby, black and tan, tri-color and blenheim (chestnut on a pearly-white background). Height: 12-13 inches $(30-33 \mathrm{~cm}$.) Weight: $10-18$ pounds (5-8 kg.) 